\title{
Improvement of fertility in repeat breeder dairy cattle by embryo transfer following artificial insemination: possibility of interferon tau replenishment effect
}

\author{
Hikari YAGINUMA ${ }^{1)^{*}}$, Natsumi FUNESHIMA ${ }^{2)^{*}}$, Nao TANIKAWA ${ }^{2)}$, Motoharu MIYAMURA ${ }^{1)}$, \\ Hideki TSUCHIYA ${ }^{1)}$, Tatsuo NOGUCHI ${ }^{3)}$, Hisataka IWATA ${ }^{2)}$, Takehito KUWAYAMA ${ }^{2)}$, \\ Koumei SHIRASUNA ${ }^{2)}$ and Seizo HAMANO ${ }^{1,4)}$
}

\author{
1) Animal Bio-Technology Center, Livestock Improvement Association of Japan Inc., Tokyo 135-0041, Japan \\ 2) Department of Animal Science, Tokyo University of Agriculture, Kanagawa 243-0034, Japan \\ 3) University Farm, Tokyo University of Agriculture, Shizuoka 418-0109, Japan \\ 4) Maebashi Institute of Animal Science, Livestock Improvement Association of Japan Inc., Gunma 371-0121, Japan
}

\begin{abstract}
Repeat breeder cattle do not become pregnant until after three or more breeding attempts; this represents a critical reproductive disorder. Embryo transfer (ET) following artificial insemination (AI) in repeat breeder cattle reportedly improves pregnancy rate, leading to speculation that interferon tau (IFNT) is associated with this phenomenon. However, the reason why the conception rate improves remains unknown. We investigated the effect of ET following AI on repeat breeder cattle in field tests, and determined whether adding an embryo affects the maternal immune cells detected by interferon-stimulated genes (ISGs), marker genes of IFN response. In total, 1122 repeat breeder cattle were implanted with in vitro fertilization (IVF) embryos after previous AI. ET following AI resulted in pregnancy rates of $46.9 \%$ in repeat breeder dairy cattle. In basic in vivo tests, to investigate the effect of adding embryos, ISGs mRNA expression levels were significantly higher in the AI + ET group than in the AI + sham group (transfer of only embryonic cryopreservation solution). Then, we examined the effect of cultured conditioned media (CM) of IVF embryos on splenic immune cells and Madin-Darby bovine kidney (MDBK) cells with stably introduced ISG15 promoter-reporter constructs. These cells exhibited a specific increase in ISG15 mRNA expression and promoter activity when treated with the CM of IVF embryos, suggesting that IVF embryos have the potential to produce and release IFNT. In conclusion, ET following AI is beneficial for improving conception in repeat breeder cattle. Added embryos may produce and secrete IFNT, resulting in the increased expression of ISGs.
\end{abstract}

Key words: Interferon tau, Interferon-stimulated gene (ISG) 15, Pregnancy, Repeat breeder cows

(J. Reprod. Dev. 65: 223-229, 2019)

$\mathbf{R}$ ecently, there has been a global decline in the fertility of lactating dairy cows, including in Japan. In addition, there is great concern that repeat breeding is one of the most critical reproductive disorders in cattle. Repeat breeders are generally described as subfertile animals without any anatomical or infectious abnormalities that do not become pregnant until after three or more breeding attempts, or that remain infertile after numerous services [1]. The incidence of repeat breeding in cattle has been reported as $14 \%$ in Japan [2], 9\% in the UK [3], 10\% in Sweden [4], 25\% in Spain [5], and 22\% in the USA [6]. Repeat breeding is one of the most important factors affecting economic success in farm management, including the increasing demand of frozen semen, cost of insemination labor,

Received: October 2, 2018

Accepted: January 21, 2019

Published online in J-STAGE: February 8, 2019

(C)2019 by the Society for Reproduction and Development

Correspondence: S Hamano (e-mail: hamano@liaj.or.jp) and K Shirasuna (e-mail: ks205312@nodai.ac.jp)

* H Yaginuma and N Funeshima contributed equally to this work.

This is an open-access article distributed under the terms of the Creative Commons Attribution Non-Commercial No Derivatives (by-nc-nd) License. (CC-BY-NC-ND 4.0: https://creativecommons.org/licenses/by-nc-nd/4.0/) and days open of cows.

The physiological cause of the repeat breeding phenomenon is likely to vary considerably and be multifactorial. Some investigations found endocrine dysfunction in repeat breeder cattle, including higher levels of progesterone ( $\mathrm{P} 4)$ with low levels of estradiol during estrus, delayed luteinizing hormone surge and resulting in the aging of oocytes and abnormal fertilization, and a slow increase in P4 levels during the early luteal phase associated with low pregnancy rates [7-9]. It is also known that qualitative changes in oocytes and follicular fluids of repeat breeder cattle occur, and result in either fertilization failure or early embryonic death [10-14]. In addition, intrauterine cytokine regulatory mechanism disorder is one of the causes of repeat breeding. Katagiri et al. [9] reported that decreased epithelial growth factor (EGF) in the endometrium on days 3 and 14 clearly distinguished repeat breeder cows from healthy control cows. Because repeat breeder syndrome is a complex disease, it is difficult to elucidate the precise onset mechanisms.

Many treatments have been proposed for the prevention of repeat breeding syndrome at both the herd and individual levels. For example, treatments, including gonadotropin-releasing hormone ( $\mathrm{GnRH})$, progesterone formulation (controlled internal drug release; CIDR), exogenous estradiol benzoate, prostaglandin (PG), and combinations 
of these, have been implemented, and improved conception rates were reported in repeat breeder dairy cattle [15-17]. Remarkably, it has been proposed that embryo transfer (ET) following artificial insemination (AI) could be used as an assisted reproductive technology to improve the conception rate of repeat breeder cattle $[1,8]$. Once pregnancy is established, embryonic trophoblast cells produce and secrete interferon tau (IFNT), a well-known pregnancy recognition signal in ruminants [18]. This would induce maternal recognition of the embryo and result in the suppression of luteolytic $\mathrm{PGF}_{2 \alpha}$ from the uterus $[19,20]$. Therefore, it is speculated that the higher pregnancy rate of ET following AI in repeat breeder cattle is due to the increased release of IFNT from the added embryos [1]. However, the exact reason why this technique improves the conception rate in cattle with reduced fertility is unknown.

Therefore, in the present study, we investigated the improvement in the conception rate of repeat breeder cattle in a large-scale field study using ET following AI. To test the hypothesis that added embryos produce and secrete IFNT to support and establish pregnancy in repeat breeder cattle, interferon-stimulated gene (ISG) 15, a marker gene of IFN response, was determined in the peripheral blood samples of repeat breeder cattle, with or without ET following AI. Finally, we checked the potential of the embryos produced via in vitro fertilization (IVF) for IFNT production and IFN responsiveness to other cells.

\section{Materials and Methods}

For in vivo experiment: In vitro maturation and fertilization

In vitro maturation and fertilization were carried out as previously described [21]. In brief, bovine ovaries obtained from a local slaughterhouse were transported to the laboratory. The cumulusoocyte complexes (COCs) were aspirated from the follicles (2-5 $\mathrm{mm}$ in diameter) and washed three times in TCM-199 (Gibco BRL, Rockville, MD, USA) containing $20 \mathrm{mM}$ HEPES supplemented with $5 \%$ fetal bovine serum (FBS; HyClone, GE Healthcare UK, Buckinghamshire, England). The COCs were matured for 20-21 h at $38.5^{\circ} \mathrm{C}$ in a humidified atmosphere with $2 \% \mathrm{CO}_{2}$. Matured oocytes were inseminated with frozen-thawed semen from a Japanese Black bull (adjusted to $2 \times 10^{7}$ cells $/ \mathrm{ml}$ ) for $5 \mathrm{~h}$ at $38.5^{\circ} \mathrm{C}$ in a humidified atmosphere with $5 \% \mathrm{CO}_{2}$ in the air, in $1 \mathrm{ml}$ of $\mathrm{BO}$ solution containing $10 \mathrm{mg} / \mathrm{ml}$ bovine serum albumin and $10 \mu \mathrm{g} / \mathrm{ml}$ heparin.

\section{For in vivo experiment: In vitro culture and embryo freezing}

After IVF, oocytes surrounded with cumulus cells were placed in fresh TCM-199 medium, and the embryos were co-cultured with cumulus cells, as previously described [21]. The culture medium was changed every 2 days. After 7 days of culture post-IVF, embryos that had developed into blastocysts with good-quality grade (grades 1 or 2) were frozen in $1.4 \mathrm{M}$ glycerol in modified TCM-199 containing $20 \mathrm{mM}$ HEPES and $0.35 \mathrm{mg} / \mathrm{ml}$ sodium bicarbonate supplemented with 5\% FCS. Embryos were transferred directly into freezing medium, and each embryo was loaded into a $0.25 \mathrm{ml}$ plastic straw (Fujihira, Tokyo, Japan). The straws were placed in an alcohol bath in a programmable freezer (EYELA, Tokyo, Japan) precooled to $-6^{\circ} \mathrm{C}$. After $1 \mathrm{~min}$, the straws were seeded, maintained for another $9 \mathrm{~min}$, then cooled to $-25^{\circ} \mathrm{C}$ at a rate of $-0.33^{\circ} \mathrm{C} / \mathrm{min}$ and kept at 5 min before being plunged into liquid nitrogen.
For in vivo experiment 1: Recipient animals and embryo transfer

Holstein heifers and cows (diagnosed as repeat breeders) from dairy farms in the east Hokkaido region of Japan were used as recipients, as defined by a previous study [1]. In brief, repeat breeder cows had the following characteristics: (1) detectable estrous behavior but occasionally abnormal estrous cycles; (2) healthy uterus and ovaries as determined by transrectal palpation; and (3) the inability to conceive after three or more inseminations following normal estrous behavior. In in vivo experiment 1 , ET was performed between 2013 and 2016. An embryo was transferred 7 or 8 days after AI (using commercially available frozen-thawed semen from Japanese Black bulls). Insemination was performed with a single straw after thawing by immersion in a $35-38^{\circ} \mathrm{C}$ water-bath. The embryo was non-surgically transferred into the uterine horn, ipsilateral to the ovary with corpus luteum. Pregnancy was determined by transrectal palpation on days 40-60 after insemination.

For in vivo experiment 2: Recipient animals, embryo transfer, and blood collections

Similar to experiment 1 as described above, 301 repeat breeder Holstein cattle from dairy farms in the east Hokkaido region were used. Briefly, the animals were divided into two groups: Group $1(n=51)$ received AI with sham (injected only with embryonic cryopreservation solution), and Group $2(\mathrm{n}=250)$ received AI with ET on days 7-8. For 17 or 16 repeat breeder cattle in each group, blood samples were taken on days 14 and 21 of the estrous cycle. Pregnancy was determined by transrectal palpation on days 40-60 after insemination.

To investigate changes in mRNA expression, whole blood was applied to the Blood RNA Card (FortiusBio LLC, San Diego, CA) following the manufacturer's protocol. The cards were dried for 2 $\mathrm{h}$, then frozen at $-20^{\circ} \mathrm{C}$, and subsequently shipped to the university and stored until analysis.

\section{For in vitro experiment: In vitro embryo production and collection of conditioned medium}

In vitro maturation, fertilization, and culture were performed in the same manner as described above. After IVF, oocytes surrounded by cumulus cells were placed in fresh TCM-199 medium, and embryos were co-cultured with cumulus cells (100 fertilized embryos/1 ml of culture medium). After 8 days of culture from the day of IVF, the growth status of the embryos was confirmed, and the culture medium was collected in five independent experiments. Of these culture-conditioned media (CM), there were 15.3 hatched blastocysts and 38.6 blastocyst embryos on average. The CM samples $(n=5)$ were frozen and stored until the following experiment.

\section{For in vitro experiment: Preparation of splenic immune cells and treatment of IFNT or CM of embryo culture}

To investigate the effect of IFNT or CM of embryo culture on other cells, we used splenocytes as a representative example of immune cells because they are similar to peripheral blood immune cells, and the spleen is also affected by pregnancy [22]. Splenic immune cells were isolated from bovine spleen tissue from a local slaughterhouse. In brief, splenic tissue was cut into small pieces, minced in PBS 
containing heparin and antibiotics (amphotericin B and gentamicin, Sigma-Aldrich, St, Louis, MO, USA) and centrifuged at $500 \times g$ for $10 \mathrm{~min}$. The pellet was resuspended and filtered (70 $\mu \mathrm{m}$, Corning Incorporated, Corning, NY, USA). The cells were washed, treated with Ammonium-Chloride-Potassium (ACK) lysing buffer (Thermo Fisher Scientific, Tokyo, Japan) for the lysis of red blood cells, and resuspended in RPMI 1640 medium (Life Technologies, Carlsbad, CA, USA) with 5\% FBS. Next, splenic immune cells were treated with or without recombinant bovine $\operatorname{IFNT}(1,10$, or $100 \mathrm{ng} / \mathrm{ml})$ [23] or the $\mathrm{CM}$ of control cells (cumulus cells only, without embryos) and IVF embryos, as described above for $6 \mathrm{~h}$ at $38^{\circ} \mathrm{C}$. After incubation, cells were collected using ISOGEN II (Nippon Gene, Tokyo, Japan) to analyze mRNA expression, and stored $-80^{\circ} \mathrm{C}$ until analysis.

\section{For in vitro experiment: ISG15 promoter luciferase assay}

To investigate IFNT activity in the CM from the embryo culture, we used MDBK cells transfected with the ISG15 promoter-reporter vector [24]. In brief, the flanking region of -1150 to +50 upstream of the bovine ISG15 gene [24] was used as the promoter for the secreted Metridia longa luciferase (Takara Bio, Shiga, Japan) reporter gene. The reporter vector and the CAG promoter-driven DsRed expression vector were co-transfected into MDBK cells by electroporation, and after 5 days, DsRed-positive cells were enriched using a MoFlo Astrios cell sorter (Bechman Coulter, Indianapolis, IN, USA). The cells were seeded at a density of $1.0 \times 10^{5}$ cells/well into 96 -well cell culture plates using DMEM/F-12 (Sigma-Aldrich, St. Louis, CA, USA) containing antibodies and 5\% FBS for $24 \mathrm{~h}$. The cells were incubated with or without recombinant bovine IFNT (10 or $100 \mathrm{ng}$ / $\mathrm{ml}$ ) or the CM of control cells (cumulus cells only, without embryos) and IVF embryos as described above, for 2, 4, 8, 12, 18, or $24 \mathrm{~h}$. After collecting the cultured medium of MDBK cells, luciferase activity was measured using the Luciferase Reporter Assay System (Promega, Madison, WI, USA) in accordance with the manufacturer's protocol. Fluorescence was measured using a microplate reader (Spark 10M; TECAN Group, Männedorf, Switzerland).

\section{RNA extraction, cDNA production, and real-time PCR}

Total RNA was prepared using ISOGEN II according to the manufacturer's instructions. RNA extraction and cDNA production were performed with a commercial kit (ReverTra Ace; Toyobo, Osaka, Japan). Real-time quantitative PCR was performed with the CFX Connect ${ }^{\mathrm{TM}}$ Real Time PCR system (Bio-Rad, Hercules, CA, USA) and a commercial kit (Thunderbird SYBR qPCR Mix; Toyobo) to detect the mRNA expressions of ISG15, MX dynamin like GTPase 1 (MX1), MX dynamin like GTPase 2 (MX2), or glyceraldehyde 3-phosphate dehydrogenase $(G A P D H)$. The primers used for real-time PCR were as follows: forward, 5'-GGTATGATGCGAGCTGAAGCACTT-3' and reverse, 5'-ACCTCCCTGCTGTCAAGGT-3' for ISG15 (accession no. NM_174366); forward, 5'- GTCCCTGCTAACGTGGACAT-3' and reverse, 5'- ACCAGGTTTCTCACCACGTC-3' for MX1 (accession no. NM_173940); forward, 5'-GGACAGCGGAATCATCAC-3' and reverse, 5'- CTCCCGCTTTGTCAGTTTCAG-3' for MX2 (accession no. NM_173941); forward, 5'-ACAGTCAAGGCAGAGAACGG-3' and reverse, 5'- CCACATACTCAGCACCAGCA-3' for GAPDH (accession no. NM_001034034). RT-qPCR was performed in duplicate with a final reaction volume of $20 \mu 1$ containing $10 \mu 1$ of SYBR
Green, $7.8 \mu \mathrm{l}$ of distilled water, $0.1 \mu \mathrm{l}$ of $100 \mu \mathrm{M}$ forward and reverse primers, and $2 \mu \mathrm{l}$ of cDNA template. The amplification program consisted of a 5 min denaturation at $95^{\circ} \mathrm{C}$ followed by 40 cycles of amplification $\left(95^{\circ} \mathrm{C}\right.$ for $15 \mathrm{sec}, 60^{\circ} \mathrm{C}$ for $20 \mathrm{sec}$, and $72^{\circ} \mathrm{C}$ for 10 $\mathrm{sec})$. The expression levels of each target gene were normalized to the corresponding GAPDH threshold cycle (CT) values using the $\Delta \Delta \mathrm{CT}$ comparative method [25]. The relative amount of each PCR product was also calculated in comparison, using GAPDH as the international standard.

\section{Statistical analysis}

All data are presented as means \pm SEM. The statistical significance of differences was assessed by Student's $t$-test or one-way ANOVA followed by Bonferroni's multiple comparison test. Probabilities less than $5 \%(\mathrm{P}<0.05)$ were considered significant.

\section{Results}

Effects of ET following AI in repeat breeder cattle: field test

As shown in Table 1, a total of 1122 repeat breeder cattle (378 heifers and 744 cows) were given IVF embryo transfers following AI within a 4-year timespan (2013-2016). The number of AIs on average was 5.91 in heifers, 6.77 in cows, and 6.34 in total cattle before this experiment. As a result of ET following AI, pregnancy rates were $51.1 \%$ in heifers, $44.8 \%$ in cows, and $46.9 \%$ in total cattle.

In this 4-year field test, we were able to obtain calving information from 381 of 526 pregnant repeat breeder cattle. The resulting proportion of single calves was $81.6 \%$ (311/381 cattle) and the proportion of twin calves was $18.4 \%$ (70/381 cattle).

Effects of ET following AI in repeat breeder cattle: basic test

As shown in Table 2, a total of 301 repeat breeder cattle were used in the basic test. The recipients had been artificially inseminated anywhere from 3 to 17 times prior to being submitted to the basic test. The pregnancy rates in the AI + ET group (48.8\%; ET of IVF embryos following AI) were significantly higher than those of the AI + sham group (23.4\%; injection of cryopreservation solution only), suggesting the promising potential of ET subsequent to $\mathrm{AI}$ as a tool to improve the fertility of repeat breeder cattle.

In this experiment, blood samples were collected on days 14 and 21 from 33 repeat breeder animals to investigate the effect of ET on the mRNA expression of ISGs in white blood cells. Figure 1 shows the representative mRNA expression of ISGs, such as ISG15, MX1, and MX2, on day 14 after estrus (7 days after administration of sham or ET). The mRNA expressions of ISG15 and MX2 were significantly higher in the AI + ET group than those in the AI + sham group, whereas there were no differences in the mRNA expression of MX1 between these groups.

To examine the effect of ET following AI on pregnancy, we focused on ISG15 and MX2 mRNA expression, which we compared between the pregnant and non-pregnant groups on days 14 and 21 in the AI + ET group (Fig. 2). The mRNA expressions of ISG15 and MX2 within the white blood cells clearly increased from day 14 to day 21 during pregnancy, which was not observed in non-pregnant repeat breeder cattle. Thus, the mRNA expressions of ISG15 and MX2 were significantly higher in the white blood cells of pregnant repeat 
Table 1. Pregnancy rates after the transfer of IVF embryos following AI into repeat breeder Holstein cattle

\begin{tabular}{lccccc}
\hline Parity & Year & No. of transfers & $\begin{array}{c}\text { No. of AIs before } \\
\text { experiment (average) }\end{array}$ & No. of pregnancies & \% pregnancies \\
\hline Heifer & 2013 & 73 & 4.81 & 42 & 57.5 \\
& 2014 & 79 & 5.93 & 43 & 54.4 \\
& 2015 & 124 & 6.46 & 71 & 57.2 \\
& 2016 & 102 & 6.44 & 37 & 36.3 \\
\cline { 2 - 6 } & 4 years & 378 & 5.91 & 193 & 51.1 \\
\hline \multirow{6}{*}{ Cow } & 2013 & 146 & 7.19 & 72 & 49.3 \\
& 2014 & 241 & 6.81 & 114 & 47.3 \\
& 2015 & 254 & 6.86 & 96 & 37.8 \\
& 2016 & 103 & 6.22 & 51 & 49.5 \\
\hline & 4 years & 744 & 6.77 & 333 & 44.8 \\
\hline All & 4 years & 1122 & 6.34 & 526 & 46.9 \\
\hline
\end{tabular}

Table 2. Pregnancy rates after the transfer of IVF embryos following AI in repeat breeder Holstein cattle

\begin{tabular}{lccc}
\hline Treatments & No. of transfers & No. of pregnancies & \% pregnancies \\
\hline AI + sham & $47(17)$ & $11(4)$ & $23.4(23.5)^{\mathrm{a}}$ \\
AI + ET & $250(16)$ & $122(7)$ & $48.8(43.8)^{\mathrm{b}}$ \\
\hline
\end{tabular}

Numbers in parentheses indicate individuals analyzed with blood sampling. a, b Different superscript indicates significant differences $(\mathrm{P}<0.05)$.

breeders than in those of non-pregnant repeat breeders on day 21 after estrus. These findings suggest that adding embryos subsequent to AI produces IFNT, increasing the mRNA expression of ISGs in peripheral blood immune cells; this may contribute to successful pregnancies in repeat breeder cattle.

\section{Effect of embryo CM and IFNT on ISG15 mRNA expression in splenic immune cells}

To investigate our hypothesis that added embryos produce IFNT and affect other cells, including peripheral immune cells, we examined the effect of the CM of IVF embryos on splenic immune cells in vitro. First, we examined whether splenic immune cells respond to IFNT. As shown in Fig. 3, recombinant IFNT significantly stimulated ISG15 mRNA expression in a dose-dependent manner, indicating that splenic immune cells have an IFNT responsiveness similar to that of peripheral immune cells. Next, we treated the CM of control cells (cumulus cells only, without embryos) and IVF embryos in splenic immune cells. Similar to recombinant IFNT treatment, ISG15 mRNA expression was clearly stimulated by treatment with the CM of IVF embryos.

\section{Effect of embryo CM and IFNT on ISG15 gene promoter activity}

To confirm the effect of cultured IVF embryos on ISG15 transcription, we used MDBK cells with stably introduced ISG15 promoterreporter constructs treated with recombinant IFNT or CM. The cells demonstrated a specific increase in reactivity with IFNT and the CM of IVF embryos, but not the cultured control CM, in a time-dependent
(A) ISG15 mRNA

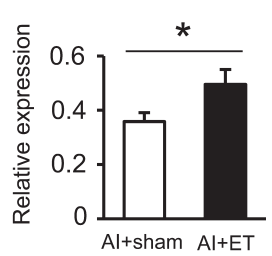

(B) MX1 mRNA

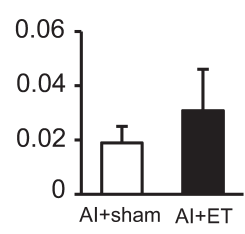

(C) MX2 mRNA

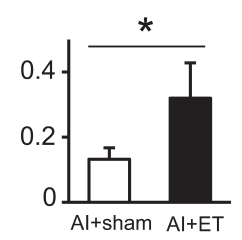

Fig. 1. mRNA expression of ISGs in white blood cells obtained from AI + sham and $\mathrm{AI}+\mathrm{ET}$ in repeat breeder cattle. Blood samples were collected on day 14 after estrus (7 days after administration of sham or ET), and the mRNA expression of ISGs, such as ISG15 (A), MX1 (B), and MX2 (C), was determined in the AI + sham (white bars, $\mathrm{n}=17$ ) and $\mathrm{AI}+\mathrm{ET}$ groups (black bars, $\mathrm{n}=16$ ). All values are shown as the mean \pm SEM (relative to GAPDH mRNA levels). * indicates significant differences $(\mathrm{P}<0.05)$ as determined by Student's $t$-test.
(A) ISG15 mRNA

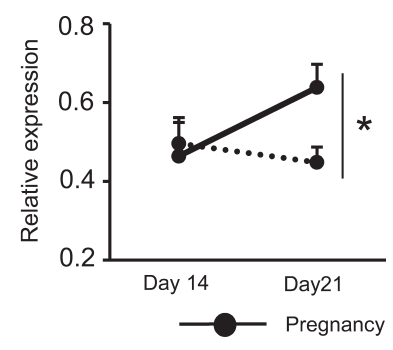

(B) MX2 mRNA

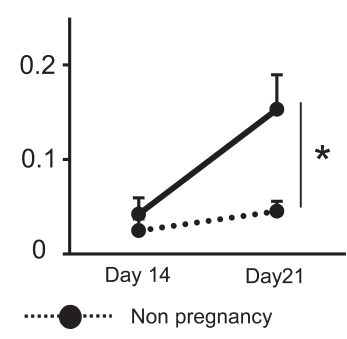

Fig. 2. mRNA expression of ISG15 and MX2 in white blood cells treated with ET following AI in repeat breeder cattle. Blood samples were collected on days 14 and 21 after estrus ( 7 and 14 days after ET), and the mRNA expression of ISG15 (A) and MX2 (B) was determined in the pregnant (solid line, $\mathrm{n}=8$ ) and non-pregnant (dashed line, $\mathrm{n}=8$ ) groups. All values are shown as the mean \pm SEM (relative to GAPDH mRNA levels). * indicates significant differences $(\mathrm{P}<0.05)$ as determined by Student's $t$-test. 
ISG15 promoter / luciferase activity

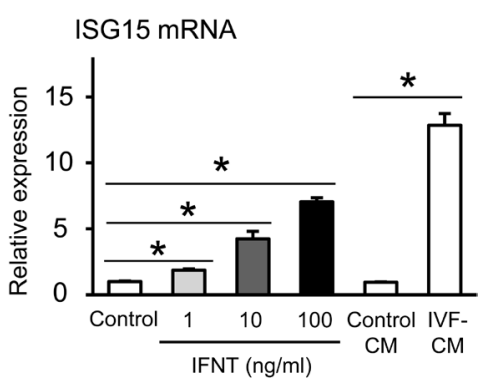

Fig. 3. Effect of embryo CM and IFNT on ISG15 mRNA expression in splenic immune cells. Splenic immune cells were isolated from the bovine spleen and treated with or without recombinant bovine IFNT $(1,10$, or $100 \mathrm{ng} / \mathrm{ml})$ or the CM of control cells (cumulus cells without embryos) and IVF embryos for $6 \mathrm{~h}$. Then, ISG15 mRNA expression was determined ( $\mathrm{n}=5$, each group). * indicates significant difference $(\mathrm{P}<0.05)$ as determined by oneway ANOVA followed by Bonferroni's multiple comparison test.

manner (Fig. 4). These findings suggest that IVF embryos, transferred in vivo, have the potential to produce and release IFNT, resulting in the stimulation of ISG15 gene expression.

\section{Discussion}

In the present study, we conducted a field test with over 1000 repeat breeder animals, in which approximately $50 \%$ of repeat breeder cattle could become pregnant by ET following AI, even when unable to conceive via AI on multiple occasions. In addition, to clarify the effect of adding embryos, we compared the pregnancy rates between sham operations of ET following AI (no embryo; AI + sham) and ETs following AI $(\mathrm{AI}+\mathrm{ET})$ in repeat breeder cattle, which resulted in significantly higher pregnancy rates in treatments with $\mathrm{AI}+\mathrm{ET}$ in repeat breeder cattle. Moreover, Dochi et al. [1] and Canu et al. [8] compared the pregnancy rates between ETs following AI and ETs only (without AI) in repeat breeder cattle, and reported the higher pregnancy rates in treatments with ETs following AI than with ETs only. On the other hand, protocols with both CIDR-based timed AI (i.e., AI only) and the synchronization of ovulation for fixed-timed ET (i.e., ET only) displayed low pregnancy rates ( $8 \%$ or $18 \%$, respectively) in repeat breeder dairy cows $[15,16]$. These findings suggest that combined treatment with ET and AI is an effective therapeutic tool for the improvement of fertility in repeat breeder cattle.

Data in the present study indicate that adding embryos allows the secretion of IFNT to support and establish pregnancy in repeat breeder cattle. This hypothesis was confirmed by increased levels in ISG mRNA expression in peripheral white blood cells at 7 days post-ET following AI compared to the AI + sham group (Fig. 1). Similar to previous studies, the mRNA expression of ISGs in the white blood cells was higher in pregnant animals than in non-pregnant animals (Fig. 2) [26-31]. Importantly, the co-transfer of bovine trophoblast vesicles with IVF embryos increases the fertility of demi-embryos during the early stages of pregnancy, suggesting that adding trophoblasts (vesicles or embryo) appear to have a potential

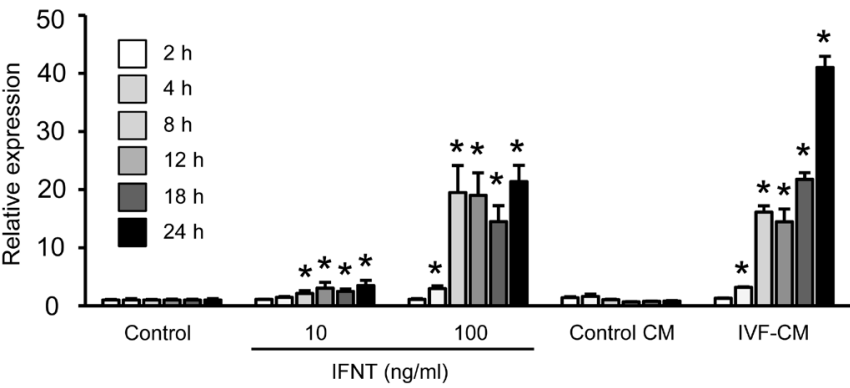

Fig. 4. Effect of embryo CM and IFNT on ISG15 gene promoter activity. MDBK cells transfected with the ISG15 promoter-reporter vector were used. The cells were incubated with or without recombinant bovine IFNT (10, or $100 \mathrm{ng} / \mathrm{ml}$ ) or the CM of control cells (cumulus cells without embryos) and IVF embryos for $2,4,8,12,18$, or $24 \mathrm{~h}(\mathrm{n}=3-4$ in each treated group each time). After collecting the cultured medium of MDBK cells, the luciferase activity was measured using the Dual-Luciferase Reporter Assay System. * indicates a significant difference compared to the control in each incubated time $(\mathrm{P}<0.05)$, as determined by one-way ANOVA followed by Bonferroni's multiple comparison test.

role in maternal pregnancy recognition via enhanced IFNT secretion $[32,33]$. In addition to its intrauterine function, IFNT produced by the conceptus passes through the endometrium and enters the uterine vein [34], playing a crucial role in the transformation of tissues during pregnancy via the systemic immune system [35]. Indeed, the expression levels of interleukin 4 (IL-4) and IL-10 inducing immune tolerance were higher in peripheral blood immune cells from pregnant cows than in those from non-pregnant cows [31, $36]$, and IFNT treatment significantly suppressed IL-1 $\beta$ and tumor necrosis factor- $\alpha$ as the major pro-inflammatory cytokines in bovine immune cells [37]. These findings suggest that IFNT generates an anti-inflammatory response in immune cells and provides an immunological tolerance to accept the embryo. Furthermore, IFNT also plays a role in regulating embryonic development and elongation in ruminants. IFNT promotes development to the blastocyst stage in vitro [38], and a loss-of-function study on IFNT demonstrated a reduced IFNT secretion, which resulted in severely growth-retarded and malformed conceptuses [39]. Therefore, it is suggested that ET following AI comprehensively increases the amount of IFNT in repeat breeder cattle, and the additional IFNT supports a maternal environment for pregnancy.

From the data showing that the conception rate was improved by supplementing IFNT via added embryos, it can be assumed that IFNT production from original embryos in repeat breeder cattle is low. However, to our knowledge, there is no previous report on IFNT production from the embryos of repeat breeder cattle. On the other hand, there are some studies investigating the oocytes or follicular fluid of repeat breeder cattle. For example, the yield of oocytes and their quality from repeat breeder dairy cows was lower than that from healthy dairy cows $[11,13]$. Moreover, after ovum pickups and IVF, blastocyst production was markedly lower in repeat breeder cows than in healthy control cows [10]. Interestingly, Kafi et al. [14] reported that the supplementation of in vitro oocyte maturation media 
with follicular fluid collected from repeat breeder Holstein heifers significantly reduced the in vitro nuclear maturation, fertilization, and blastocyst yield. These findings demonstrated that oocytes and follicles of repeat breeder cattle qualitatively decline, suggesting that the quality of embryos and IFNT production may be low as a result of the deterioration of the maternal ovarian microenvironment.

In addition to the endocrine condition and maternal ovarian microenvironment, it is suggested that the uterine environment of repeat breeder cattle is less suitable for supporting successful embryo development. Using the ET technique, Gustafsson and Larsson [40] reported that a lower ratio of embryos were transferred from healthy heifers to repeat breeder heifers (two out of nine) than from repeat breeder heifers to healthy heifers (five out of six). Moreover, Kimura et al. [41] reported essential data using an elongated ET technique, in which elongating embryos collected from normal cows on day 14 were transferred to healthy control or repeat breeder cows, resulting in a lower pregnancy rate within repeat breeder cows $(2.4 \%)$ than within reproductive control cows (54.5\%). Furthermore, it is reported that endometrial gene expression profiles are different between repeat breeder cows and non-repeat breeder cows [42]. These findings indicate that the uterine environment of repeat breeder cattle is suboptimal and gradually deteriorates in terms of supporting normal embryonic development.

Many attempts to use hormonal treatment have been undertaken to improve the conception of repeat breeder cattle. Katagiri et al. [9, 43] demonstrated that an alteration in the cyclic change of endometrial EGF concentrations was displayed in repeat breeder Holstein cows but not heifers. They showed that recipient cows with EGF levels below the normal range on day 3 exhibited a lower conception rate (equal to repeat breeder cows) than those with EGF levels within the normal range. Moreover, repeat breeder cows with low EGF levels were treated with a high dose of estradiol benzoate and a CIDR device showed the restoration of a normal EGF profile and higher fertility. Interestingly, Lange-Consiglio et al. [44] attempted to improve fertility in repeat breeder cattle by using platelet concentrate (PC); they showed in an in vitro study that PC had the potential to increase embryo production and quality. Remarkably, the intrauterine administration of PC to repeat breeder cows at $48 \mathrm{~h}$ after AI significantly improved the pregnancy rate $(70 \%)$ compared to that of the control group (33.3\%). The study also discussed the role of platelets as a regulatory factor producing many cytokines, such as EGF, platelet derived growth factor, and fibroblast growth factor, determining that these cytokines are able to stimulate bovine embryo development [44]. These findings indicate the importance of cytokine conditions within the uterine environment for the establishment of pregnancy. From these results, we hypothesize that ET following AI may have the potential to regulate the uterine microenvironment and improve conception in repeat breeder cattle; however, further investigations are required to confirm this hypothesis.

Because embryos can be generated with ET following AI, the increase in the proportion of twin pregnancies is concerning. It has been reported that the proportion of twins occurring during normal $\mathrm{AI}$ is $0.3 \%-5 \%$ in dairy cattle [45]. Previously, Sreenan and Diskin [46] reported that the rate of twinning was 55\%-60\% with ET following AI in control heifers. Conversely, in our study, the rate of twin occurrence in repeat breeder cattle was $18.4 \%$, lower than their result and consistent with previous studies conducting ET following AI, reporting rates of $6.25 \%$ [1] and $8.8 \%$ [8]. Although the ratio of labor accident is unknown in the present study, it is necessary to consider an alternative method that avoids twin generation for the improvement of conception in repeat breeder cattle in the future.

In conclusion, ET following AI is beneficial for the improvement of conception in repeat breeder cattle. Added embryos produce and secrete IFNT, resulting in an increased expression of ISGs. Additionally, it is suggested that added embryos may have the potential to regulate the uterine microenvironment to establish pregnancy in repeat breeder cattle.

Conflict of interest: The authors declare no conflict of interest.

\section{Acknowledgments}

We are grateful to Ryosuke Sakumoto, Misa Hosoe, and Tadashi Furusawa (National Agriculture and Food Research Organization) for dispensing recombinant IFNT and MDBK cells transfected with the ISG15 promoter-reporter vector. We are grateful to Tomohiro Tomikawa (Japan Agricultural Cooperatives in Honbetsu), Taiki Izumi (Tokachi NOSAI), Satoshi Kayaoka (Japan Agricultural Cooperatives in Kenebetsu), Shinjiro Sugiura, and Takeshi Iwai (Agricultural Insurance Hidaka branch) for their data collection in field tests.

This study was supported by Livestock Promotional Funds of the Japan Racing Association (KS).

\section{References}

1. Dochi O, Takahashi K, Hirai T, Hayakawa H, Tanisawa M, Yamamoto Y, Koyama H. The use of embryo transfer to produce pregnancies in repeat-breeding dairy cattle. Theriogenology 2008; 69: 124-128. [Medline] [CrossRef]

2. Yusuf M, Nakao T, Ranasinghe RB, Gautam G, Long ST, Yoshida C, Koike K, Hayashi A. Reproductive performance of repeat breeders in dairy herds. Theriogenology 2010; 73: 1220-1229. [Medline] [CrossRef]

3. Bulman DC, Lamming GE. Milk progesterone levels in relation to conception, repeat breeding and factors influencing acyclicity in dairy cows. J Reprod Fertil 1978; 54: 447-458. [Medline] [CrossRef]

4. Gustafsson H, Emanuelson U. Characterisation of the repeat breeding syndrome in Swedish dairy cattle. Acta Vet Scand 2002; 43: 115-125. [Medline] [CrossRef]

5. Garcia-Ispierto I, López-Gatius F. Progesterone supplementation in the early luteal phase after artificial insemination improves conception rates in high-producing dairy cows. Theriogenology 2017; 90: 20-24. [Medline] [CrossRef]

6. Bartlett PC, Kirk JH, Mather EC. Repeated insemination in Michigan Holstein-Friesian cattle: Incidence, descriptive epidemiology and estimated economic impact. Theriogenology 1986; 26: 309-322. [Medline] [CrossRef]

7. Båge R, Gustafsson H, Larsson B, Forsberg M, Rodríguez-Martínez H. Repeat breeding in dairy heifers: follicular dynamics and estrous cycle characteristics in relation to sexual hormone patterns. Theriogenology 2002; 57: 2257-2269. [Medline] [CrossRef]

8. Canu S, Boland M, Lloyd GM, Newman M, Christie MF, May PJ, Christley RM, Smith RF, Dobson H. Predisposition to repeat breeding in UK cattle and success of artificial insemination alone or in combination with embryo transfer. Vet Rec 2010; 167: 44-51. [Medline] [CrossRef]

9. Katagiri S, Moriyoshi M. Alteration of the endometrial EGF profile as a potential mechanism connecting the alterations in the ovarian steroid hormone profile to embryonic loss in repeat breeders and high-producing cows. J Reprod Dev 2013; 59: 415-420. [Medline] [CrossRef]

10. Sood P, Zachut M, Dekel I, Dube H, Jacoby S, Moallem U. Preovulatory follicle characteristics and oocyte competence in repeat breeder dairy cows. J Dairy Sci 2017; 100: 9372-9381. [Medline] [CrossRef]

11. Kurykin J, Waldmann A, Tiirats T, Kaart T, Jaakma U. Morphological quality of oocytes and blood plasma metabolites in repeat breeding and early lactation dairy cows. 
Reprod Domest Anim 2011; 46: 253-260. [Medline] [CrossRef]

12. Puglisi R, Cambuli C, Capoferri R, Giannino L, Lukaj A, Duchi R, Lazzari G, Galli C, Feligini M, Galli A, Bongioni G. Differential gene expression in cumulus oocyte complexes collected by ovum pick up from repeat breeder and normally fertile Holstein Friesian heifers. Anim Reprod Sci 2013; 141: 26-33. [Medline] [CrossRef]

13. Awasthi H, Saravia F, Rodríguez-Martínez H, Båge R. Do cytoplasmic lipid droplets accumulate in immature oocytes from over-conditioned repeat breeder dairy heifers? Reprod Domest Anim 2010; 45: e194-e198. [Medline]

14. Kafi M, Azari M, Chashnigir O, Gharibzadeh S, Aghabozorgi Z, Asaadi A, Divar MR. Inherent inferior quality of follicular fluid in repeat breeder heifers as evidenced by low rates of in vitro production of bovine embryos. Theriogenology 2017; 102: 29-34. [Medline] [CrossRef]

15. Son DS, Choe CY, Cho SR, Choi SH, Kim HJ, Hur TY, Jung YG, Kang HG, Kim IH. A CIDR-based timed embryo transfer protocol increases the pregnancy rate of lactating repeat breeder dairy cows. J Reprod Dev 2007; 53: 1313-1318. [Medline] [CrossRef]

16. Rodrigues CA, Teixeira AA, Ferreira RM, Ayres H, Mancilha RF, Souza AH, Baruselli PS. Effect of fixed-time embryo transfer on reproductive efficiency in highproducing repeat-breeder Holstein cows. Anim Reprod Sci 2010; 118: 110-117. [Medline] [CrossRef]

17. Kim UH, Suh GH, Hur TY, Kang SJ, Kang HG, Park SB, Kim HS, Kim IH. Comparison of two types of CIDR-based timed artificial insemination protocols for repeat breeder dairy cows. J Reprod Dev 2007; 53: 639-645. [Medline] [CrossRef]

18. Imakawa K, Anthony RV, Kazemi M, Marotti KR, Polites HG, Roberts RM. Interferon-like sequence of ovine trophoblast protein secreted by embryonic trophectoderm. Nature 1987; 330: 377-379. [Medline] [CrossRef]

19. Meyer MD, Hansen PJ, Thatcher WW, Drost M, Badinga L, Roberts RM, Li J, Ott TL, Bazer FW. Extension of corpus luteum lifespan and reduction of uterine secretion of prostaglandin F2 alpha of cows in response to recombinant interferon-tau. J Dairy Sci 1995; 78: 1921-1931. [Medline] [CrossRef]

20. Spencer TE, Burghardt RC, Johnson GA, Bazer FW. Conceptus signals for establishment and maintenance of pregnancy. Anim Reprod Sci 2004; 82-83: 537-550. [Medline] [CrossRef]

21. Hamano S, Kuwayama M. In vitro fertilization and development of bovine oocytes recovered from the ovaries of individual donors: A comparison between the cutting and aspiration method. Theriogenology 1993; 39: 703-712. [Medline] [CrossRef]

22. Yang L, Guo R, Yao X, Yan J, Bai Y, Zhang L. Expression of progesterone receptor and progesterone-induced blocking factor in the spleen during early pregnancy in ewews. Livest Sci 2018; 209: 14-19. [CrossRef]

23. Takahashi T, Sakumoto R, Hayashi KG, Hosoe M, Shirai J, Hashizume K. Generation of recombinant bovine interferon tau in the human embryonic kidney cell line and its biological activity. Anim Sci J 2017; 88: 1498-1505. [Medline] [CrossRef]

24. Toji N, Koshi K, Furusawa T, Takahashi T, Ishiguro-Oonuma T, Kizaki K, Hashizume K. A cell-based interferon-tau assay with an interferon-stimulated gene 15 promoter. Biomed Res 2018; 39: 13-20. [Medline] [CrossRef]

25. Livak KJ, Schmittgen TD. Analysis of relative gene expression data using real-time quantitative PCR and the 2(-Delta Delta C(T)) Method. Methods 2001; 25: 402-408. [Medline] [CrossRef]

26. Sheikh AA, Hooda OK, Kalyan A, Kamboj A, Mohammed S, Alhussien M, Reddi S, Shimray PG, Rautela A, Pandita S, Kapila S, De S, Dang AK. Interferon-tau stimulated gene expression: A proxy to predict embryonic mortality in dairy cows. Theriogenology 2018; 120: 61-67. [Medline] [CrossRef]

27. Gifford CA, Racicot K, Clark DS, Austin KJ, Hansen TR, Lucy MC, Davies CJ, Ott TL. Regulation of interferon-stimulated genes in peripheral blood leukocytes in pregnant and bred, nonpregnant dairy cows. J Dairy Sci 2007; 90: 274-280. [Medline] [CrossRef]

28. Hansen TR, Henkes LK, Ashley RL, Bott RC, Antoniazzi AQ, Han H. Endocrine actions of interferon-tau in ruminants. Soc Reprod Fertil Suppl 2010; 67: 325-340. [Medline]

29. Han H, Austin KJ, Rempel LA, Hansen TR. Low blood ISG15 mRNA and progesterone levels are predictive of non-pregnant dairy cows. J Endocrinol 2006; 191: 505-512.
[Medline] [CrossRef]

30. Yang L, Wang XL, Wan PC, Zhang LY, Wu Y, Tang DW, Zeng SM. Up-regulation of expression of interferon-stimulated gene 15 in the bovine corpus luteum during early pregnancy. J Dairy Sci 2010; 93: 1000-1011. [Medline] [CrossRef]

31. Shirasuna K, Matsumoto H, Kobayashi E, Nitta A, Haneda S, Matsui M, Kawashima C, Kida K, Shimizu T, Miyamoto A. Upregulation of interferon-stimulated genes and interleukin-10 in peripheral blood immune cells during early pregnancy in dairy cows. $J$ Reprod Dev 2012; 58: 84-90. [Medline] [CrossRef]

32. Hashiyada $\mathbf{Y}$, Okada M, Imai $\mathbf{K}$. Transition of the pregnancy rate of bisected bovine embryos after co-transfer with trophoblastic vesicles prepared from in vivo-cultured in vitro-fertilized embryos. J Reprod Dev 2005; 51: 749-756. [Medline] [CrossRef]

33. Mori M, Kasa S, Hattori MA, Ueda S. Development of a single bovine embryo improved by co-culture with trophoblastic vesicles in vitamin-supplemented medium. $J$ Reprod Dev 2012; 58: 717-721. [Medline] [CrossRef]

34. Oliveira JF, Henkes LE, Ashley RL, Purcell SH, Smirnova NP, Veeramachaneni DN, Anthony RV, Hansen TR. Expression of interferon (IFN)-stimulated genes in extrauterine tissues during early pregnancy in sheep is the consequence of endocrine IFN-tau release from the uterine vein. Endocrinology 2008; 149: 1252-1259. [Medline] [CrossRef]

35. Bott RC, Ashley RL, Henkes LE, Antoniazzi AQ, Bruemmer JE, Niswender GD, Bazer FW, Spencer TE, Smirnova NP, Anthony RV, Hansen TR. Uterine vein infusion of interferon tau (IFNT) extends luteal life span in ewes. Biol Reprod 2010; 82: 725-735. [Medline] [CrossRef]

36. Yang L, Wang Y, Li S, Zhu M, He K, Yao X, Zhang L. Differential expression of interferon-gamma, IL-4 and IL-10 in peripheral blood mononuclear cells during early pregnancy of the bovine. Reprod Biol 2018; 18: 312-315. [Medline] [CrossRef]

37. Rashid MB, Talukder AK, Kusama K, Haneda S, Takedomi T, Yoshino H, Moriyasu S, Matsui M, Shimada M, Imakawa K, Miyamoto A. Evidence that interferon-tau secreted from Day-7 embryo in vivo generates anti-inflammatory immune response in the bovine uterus. Biochem Biophys Res Commun 2018; 500: 879-884. [Medline] [CrossRef]

38. Takahashi M, Takahashi H, Hamano S, Watanabe S, Inumaru S, Geshi M, Okuda K, Yokomizo Y, Okano A. Possible role of interferon-tau on in vitro development of bovine embryos. J Reprod Dev 2003; 49: 297-305. [Medline] [CrossRef]

39. Brooks K, Spencer TE. Biological roles of interferon tau (IFNT) and type I IFN receptors in elongation of the ovine conceptus. Biol Reprod 2015; 92: 47. [Medline] [CrossRef]

40. Gustafsson H, Larsson K. Embryonic mortality in heifers after artificial insemination and embryo transfer: differences between virgin and repeat breeder heifers. Res Vet Sci 1985; 39: 271-274. [Medline] [CrossRef]

41. Kimura K, Matsuyama S, Kojima T. Effect of transfer of cattle elongating embryo to a repeat breeder cow on pregnancy rate and incidence of a return to estrus. Reprod Fertil Dev 2010; 23: 145.

42. Hayashi KG, Hosoe M, Kizaki K, Fujii S, Kanahara H, Takahashi T, Sakumoto R. Differential gene expression profiling of endometrium during the mid-luteal phase of the estrous cycle between a repeat breeder (RB) and non-RB cows. Reprod Biol Endocrinol 2017; 15: 20. [Medline] [CrossRef]

43. Katagiri S, Moriyoshi M, Takahashi Y. Low incidence of an altered endometrial epidermal growth factor (EGF) profile in repeat breeder Holstein heifers and differential effect of parity on the EGF profile between fertile Holstein (dairy) and Japanese Black (beef) cattle. J Reprod Dev 2013; 59: 575-579. [Medline] [CrossRef]

44. Lange-Consiglio A, Cazzaniga N, Garlappi R, Spelta C, Pollera C, Perrini C, Cremonesi F. Platelet concentrate in bovine reproduction: effects on in vitro embryo production and after intrauterine administration in repeat breeder cows. Reprod Biol Endocrinol 2015; 13: 65. [Medline] [CrossRef]

45. Miyake Y, Miyoshi K, Moriya H, Matsui M, Haneda S. Stduies on the accident rate in single and multiple births in dairy cows. Jpn J Large Anim Clin 2010; 1: 5-9. [CrossRef]

46. Sreenan JM, Diskin MG. Effect of a unilateral or bilateral twin embryo distribution on twinning and embryo survival rate in the cow. J Reprod Fertil 1989; 87: 657-664. [Medline] [CrossRef] 